\title{
THE RELATIONSHIP BETWEEN LEARNING DISCIPLINE, INTERESTS OF LEARNING AND LEARNING ENVIRONMENT AT HOME WITH MATHEMATICS LEARNING OUTCOME OF STUDENTS SMP NEGERI 15 YOGYAKARTA
}

\author{
Budi Prabowo ${ }^{\text {a }}$, Abdul Taram ${ }^{\mathrm{b}}$ \\ Program Studi Pendidikan Matematika Universitas Ahmad Dahlan \\ Jalan Ring Road Selatan, Tamanan, Banguntapan, Bantul Yogyakarta

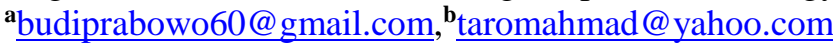

\begin{abstract}
Low mathematics learning outcomes are thought to be related to several factors. These factors include learning discipline, interest in learning and learning environment at home. This study aims to determine the presence or absence of a positive and significant relationship between learning discipline, learning interest and learning environment at home with mathematics learning outcomes for students of class VIII of SMP Negeri 15 Yogyakarta in 2015/2016 Academic Year. The population in this study were all regular students of class VIII in the even semester of SMP Negeri 15 Yogyakarta with 5 classes. A sample of 1 class with 27 students was taken by cluster random sampling technique obtained by class VIII B as a research class. Data collection techniques using a questionnaire method to determine the discipline of learning, interest in learning and learning environment at home students, and test methods to determine student learning outcomes in mathematics. To test the instrument using a validity test, reliability testing and distinguishing power test. After the data is collected, an analysis prerequisite test is conducted which includes a normality test, an independence test, and a linearity test. Data analysis for hypothesis testing uses product-moment correlation analysis, multiple linear regression analysis for 2 variables and multiple regression analysis for 3 variables. The results showed there was a positive and significant relationship between learning discipline, learning interest and learning environment at home with mathematics learning outcomes, with $\hat{Y}=-193,541+$ $1,465 X_{1}+1,047 X_{2}+0,35 X_{3}$. Relative contribution $X_{1}=58,95661 \%, X_{2}=34,39229 \%$ dan $X_{3}=$ $6,651091 \%$ and effective donations $X_{1}=39,94658 \%, X_{2}=23,30281 \%$ dan $X_{3}=4,506506 \%$.
\end{abstract}

Keywords: Learning Discipline, Interest in Learning, Learning Environment, Learning Outcomes

\section{INTRODUCTION}

Education is one of the factors used as a benchmark for the progress of a nation. This proves that education is very important for every individual and country. Education plays an important role in development, especially to improve the quality of human resources. Efforts to improve the quality of education are an integrated part of efforts to improve quality, both aspects of ability, personality, and responsibility as citizens. The word mathematics is certainly no stranger to us because mathematics is one of the sciences where material is needed in all majors that are studied by everyone. Mathematics is also one of the fields of study that occupies an important role in education because when viewed from the time of school hours at school more than other subjects. Because many factors affect the learning process, causing low student learning outcomes in mathematics. This can be seen from the average value of daily tests (UH) of the subject of algebraic operation class VIII C Yogyakarta 15 Junior High School in mathematics, less than $50 \%$ of students who meet the minimum completeness criteria (KKM), with KKM 75.

Less than optimal learning outcomes in mathematics at SMP Negeri 15 Yogyakarta allegedly caused by several things including lack of student discipline, low student interest in learning and less conducive student learning environment at home. Based on this, the study took several variables as internal factors that might be related to student learning outcomes. These factors include learning discipline and interest in learning, while external factors are the learning environment at home. Learning discipline is thought to be related to student learning outcomes. Discipline is one thing that is very important and needed by every student. Slameto (2010: 67) states that school discipline is closely related to the craft of students in school and also in learning. School discipline includes the discipline of 
teachers, principals, employees and their students. According to Moenir (2006: 94) discipline is a form of obedience to the rules, both written and unwritten, which have been determined. Interest is an internal factor that is thought to be related to mathematics learning outcomes. According to Syah, Muhibbin (2004: 136) simply, interest means a tendency and high enthusiasm or a great desire for something. According to Slameto (2010: 180), that interest is a sense of preference and a sense of attachment to a thing or activity, without anyone asking. Another case with the opinion expressed by Winkel (1996: 359) that students who have an interest, want to fulfill the need to enrich themselves, be positive towards learning in school and aspire to progress, are in conditions that allow cognitive abilities to develop; these students explore meaning and get satisfaction.

An external factor thought to be related to student mathematics learning outcomes is the learning environment at home. Syah, Muhibbin (2004: 137) argues that the social environment that most influences learning activities is the parents and families of the students themselves. According Arikunto, Suharsimi, (2012: 12) said that the availability of a comfortable learning place, with sufficient space, lighting, and ventilation, whether the learning time is not interrupted by other activities at home, books needed by students are provided by parents, as well as a comfortable family environment that allows students to learn in peace.

The problems in this study are: 1) Discipline of students to study at school and at home is still lacking. 2) Student's learning interest is very low. 3) many student learning environments are less conducive. 4) The learning outcomes of students of SMP Negeri 15 Yogyakarta are not optimal. Some students' mathematics learning outcomes are still below the KKM score.

The purpose of this study was to find out: 1) Whether there was a relationship between learning discipline and mathematics learning outcomes for students of class VIII of SMP Negeri 15 Yogyakarta in the academic year 2015/2016. 2) Whether there is a relationship between interest in learning with mathematics learning outcomes for students of class VIII at SMP Negeri 15 Yogyakarta in the 2015/2016 academic year. / 2016. 4) Whether there is a relationship between learning discipline and learning interest with the learning outcomes of eighth-grade students of SMP Negeri 15 Yogyakarta in the 2015/2016 academic year. 5) Whether there is a relationship between learning discipline and the learning environment at home with the results of mathematics learning for eighth-grade students of SMP Negeri 15 Yogyakarta in the 2015/2016 academic year. 6) Whether there is a relationship between interest in learning and the learning environment at home mathematics with the learning outcomes of students of class VIII of SMP Negeri 15 Yogyakarta in the 2015/2016 academic year. 7) Whether there is a relationship between learning discipline, interest in learning and the learning environment at home with the mathematics learning outcomes of students of class VIII at SMP Negeri 15 Yogyakarta in the 2015/2016 school year.

\section{METHODS}

This research is classified as quantitative research and includes a type of correlation research with a population of regular VIII grade students of SMP Negeri 15 Yogyakarta in the academic year 2015/2016, which consists of 154 students consisting of 5 classes, namely classes VIII A, VIII B, VIII C, VIII D and VIII E The selection of regular class as a population class is due to the separation between regular class and KMS class in SMP Negeri 15 Yogyakarta. Sampling was done using random sampling techniques to the class. The research sample consisted of 27 students in class VIII B and class VIII C as a trial class. Data collection techniques used were questionnaires and test methods. The questionnaire is used for variables of learning discipline, learning interest and learning environment at home. While the test is used for mathematics learning outcome variables. The research instrument tests used were validity, different power tests, and reliability tests. Then for the prerequisite test analysis used is the normality test, linearity test, and independence test. Data analysis for hypothesis testing uses correlation analysis and linear regression analysis. 


\section{RESULTS AND DISCUSSION}

\section{Regression Analysis Prerequisite Test}

The summary of normality test results can be seen in Table 1 .

Table 1. Summary of Normality Test Results

\begin{tabular}{|c|c|c|c|}
\hline Variable & $\boldsymbol{X}_{\text {count }}^{2}$ & $\boldsymbol{\chi}_{\text {table }}^{2}$ & $\mathbf{D f}$ \\
\hline $\mathrm{X}_{1}$ & 7,6605 & 7,8147 & 3 \\
\hline $\mathrm{X}_{2}$ & 2,1244 & 7,8147 & 3 \\
\hline $\mathrm{X}_{3}$ & 6,1363 & 7,8147 & 3 \\
\hline $\mathrm{Y}$ & 0,9718 & 5,9915 & 2 \\
\hline
\end{tabular}

From the normality test at a significant level of $5 \%$ seen $X_{\text {count }}^{2} \leq X_{\text {table }}^{2}$ this means that the distribution of data obtained in each variable is normal.

The summary of independent test results can be seen in Table 2 .

Table 2. Summary of Independent Test Results

\begin{tabular}{|c|c|c|}
\hline Variable & $\boldsymbol{X}_{\text {count }}^{\mathbf{2}}$ & $\boldsymbol{\chi}_{\text {table }}^{\mathbf{2}}$ \\
\hline $\mathrm{X}_{1}$ and $\mathrm{X}_{2}$ & 29,057 & 37.652 \\
\hline $\mathrm{X}_{1}$ and $\mathrm{X}_{3}$ & 20,756 & 37.652 \\
\hline $\mathrm{X}_{2}$ and $\mathrm{X}_{3}$ & 35,813 & 37.652 \\
\hline
\end{tabular}

From an independent test at a significant level of $5 \%(\alpha=0.05)$ and degrees of freedom $(\mathrm{df})=$ (B-1) (K-1) seen $X_{\text {count }}^{2} \leq X_{\text {table }}^{2}$, this means that the data obtained from each variable is independent.

The summary of linearity test results can be seen in Table 3 .

Table 3. Summary of Linearity Test Results

\begin{tabular}{|c|c|c|}
\hline Variable & $\boldsymbol{F}_{\text {count }}$ & $\boldsymbol{F}_{\text {table }}$ \\
\hline $\mathrm{X}_{1}$ againts $\mathrm{Y}$ & 2,837 & 2,85 \\
\hline $\mathrm{X}_{2}$ againts $\mathrm{Y}$ & 1,578 & 2,99 \\
\hline $\mathrm{X}_{3}$ againts $\mathrm{Y}$ & 0,652 & 3,47 \\
\hline
\end{tabular}

From an independent test at a significant level of $5 \%(\alpha=0.05)$ and the degree of freedom of the numerator $v_{1}=k-2$ and the denominator's degree of freedom $v_{2}=N-k$, seen $F_{\text {count }} \leq F_{\text {table }}$, this means that the data obtained from each variable is linear.

\section{Hypothesis Testing}

From the first hypothesis test at a significant level of $5 \%$ and $\mathrm{df}=26$, it can be seen that $t_{\text {count }}=5,518299 t_{\text {table }}=1,7056$ so that $t_{\text {count }}>t_{\text {table }}$ This means there is a positive and significant relationship between learning discipline and mathematics learning outcomes for students of class VIII of SMP Negeri 15 Yogyakarta in the academic year 2015/2016. The first hypothesis test obtained a simple correlation coefficient (r) of 0.741051 which means the relationship between self-confidence and mathematics learning outcomes has a weak relationship. Obtained a determinant coefficient $\left(\mathrm{r}^{2}\right)$ of 0.549157 which can be explained that $54.91 \%$ of learning outcomes are influenced by learning discipline while the rest is influenced by other factors. There is a variation in mathematics learning outcomes $(\mathrm{Y})$ explained by learning discipline $\left(\mathrm{X}_{1}\right)$ through linear lines $\hat{Y}=-122,524+2,014 \mathrm{X}_{1}$.

From the second hypothesis test at a significant level of $5 \%$ and $\mathrm{df}=26$, it can be seen that $t_{\text {count }}=3,663746 t_{\text {table }}=1,7056$ so that $t_{\text {count }}>t_{\text {table }}$ which means that there is a positive and significant relationship between interest in learning with mathematics learning outcomes for students of class VIII SMP Negeri 15 Yogyakarta in the academic year 2015/2016. In the second hypothesis test, the correlation coefficient obtained (r) 0.591057, which means the relationship between learning interest with learning outcomes in mathematics has a weak relationship. Obtained a determinant coefficient $\left(\mathrm{r}^{2}\right)$ of 0.349349 which can be explained that $34.93 \%$ of learning outcomes are influenced by learning interest while the rest is influenced by other factors. There are 
variations in mathematics learning outcomes $(\mathrm{Y})$ which are explained by interest in learning $\left(\mathrm{X}_{2}\right)$ through linear lines. $\hat{Y}=-67,641+1,5696 \mathrm{X}_{2}$.

From the third hypothesis test at a significant level of $5 \%$ and $\mathrm{df}=26$, it can be seen that $t_{\text {count }}=1,872716 t_{\text {table }}=1,7056$ so that $t_{\text {count }}>t_{\text {table }}$ This means that there is a positive and significant relationship between the learning environment at home with the mathematics learning outcomes of Grade VIII students of SMP Negeri 15 Yogyakarta in the academic year 2015/2016. In the third hypothesis test, the correlation coefficient obtained (r) of 0.350748 which means the relationship between the use of learning resources with learning outcomes in mathematics has a weak relationship. Obtained a determinant coefficient $\left(\mathrm{r}^{2}\right)$ of 0.123024 which can be explained that $12.30 \%$ learning outcomes are influenced by the learning environment at home while the rest is influenced by other factors. There are variations in mathematics learning outcomes $(\mathrm{Y})$ which are explained by the learning environment at home $\left(\mathrm{X}_{3}\right)$ through a linear line $\hat{Y}=-15,729+$ $0,9555 X_{3}$.

From the fourth hypothesis test at a significant level of $5 \%$ and $\mathrm{v}_{1}$ numerator $=2$ and $\mathrm{v}_{2}$ numerator $=25$ so that it can be obtained $F_{\text {count }}=20,20416$ and $F_{\text {table }}=3,4$ so that $F_{\text {count }}>$ $F_{\text {table }}$ which means that there is a positive and significant relationship between learning discipline and interest in learning with mathematics learning outcomes for students of class VIII of SMP Negeri 15 Yogyakarta in the academic year 2015/2016. From the multiple correlation analysis, it is obtained the value of the multiple correlation coefficient (R) of 0.792072 which means the relationship between learning discipline and learning interest with learning outcomes in mathematics has a weak relationship. In this study also obtained a coefficient of determination $\left(\mathrm{R}^{2}\right)$ of 0.627377 meaning $62.73 \%$ of learning outcomes are influenced by learning discipline and learning interest while the rest is influenced by other factors. There are variations in mathematics learning outcomes $(\mathrm{Y})$ which can be explained by learning discipline $\left(\mathrm{X}_{1}\right)$ and learning interest $\left(\mathrm{X}_{2}\right)$ through linear lines $\hat{Y}=-158,17+1,6168 X_{1}+0,838 X_{2}$.

From the fifth hypothesis test at a significant level of $5 \%$ and the numerator, $\mathrm{v}_{1}=2$ and the numerator $\mathrm{v}_{2}=25$ so that it can be obtained $F_{\text {count }}=18,59521$ and $F_{\text {table }}=3,4$ so that $F_{\text {count }}>$ $F_{\text {table }}$ this means that there is a positive and significant relationship between learning discipline and the learning environment at home with mathematics learning outcomes for students of class VIII of SMP Negeri 15 Yogyakarta in the academic year 2015/2016. From the multiple correlation analysis, it is obtained the value of the multiple correlation coefficient (R) of 0.779604 which means that the relationship between learning discipline and the learning environment at home with mathematics learning outcomes has a weak relationship. In this study also obtained a coefficient of determination $\left(\mathrm{R}^{2}\right)$ of 0.607782 meaning $60.77 \%$ of learning outcomes are influenced by learning discipline and learning environment at home while the rest is influenced by other factors. There are variations in mathematics learning outcomes $(\mathrm{Y})$ that can be explained by disciplined learning $\left(\mathrm{X}_{1}\right)$ and the learning environment at home $\left(\mathrm{X}_{3}\right)$ through linear lines $\widehat{\mathrm{Y}}=-173,06+1,9139 X_{1}+$ $0,6672 X_{3}$.

From the sixth hypothesis test at a significant level of $5 \%$ and $\mathrm{v}_{1}$ numerator $=2$ and $\mathrm{v}_{2}$ numerator $=25$ so that it can be obtained $F_{\text {count }}=6,470842$ and $F_{\text {table }}=3,4$ so that $F_{\text {count }}>$ $F_{\text {table }}$ This means that there is a positive and significant relationship between learning interest and the learning environment at home with the mathematics learning outcomes of students of class VIII of SMP Negeri 15 Yogyakarta in the 2015/2016 academic year. From the multiple correlation analysis obtained by the value of the multiple correlation coefficient (R) of 0.591884 which means the relationship between learning interest and learning environment at home with mathematics learning outcomes has a weak relationship. This study also obtained a coefficient of determination $\left(\mathrm{R}^{2}\right)$ of 0.350327 meaning 35, 03\% of learning outcomes are influenced by interest in learning and learning environment at home while the rest is influenced by other factors. There are variations in mathematics learning outcomes $(\mathrm{Y})$ that can be explained by interest in learning $\left(\mathrm{X}_{2}\right)$ and the learning environment at home $\left(\mathrm{X}_{3}\right)$ through linear lines $\hat{Y}=-72,028+1,515 X_{2}+0,1019 X_{3}$. 
From the seventh hypothesis test at a significant level of 5\% and the numerator, $\mathrm{v}_{1}=3$ and the numerator $\mathrm{v}_{2}=23$ so that it can be obtained $F_{\text {count }}=16,1102$ and $F_{\text {table }}=3,4$ so that $F_{\text {count }}>F_{\text {table }}$ which means that there is a positive and significant relationship between learning discipline, interest in learning and learning environment at home with mathematics learning outcomes for students of class VIII at SMP Negeri 15 Yogyakarta in the academic year 2015/2016. From the multiple correlation analysis, it is obtained the value of the multiple correlation coefficient $(\mathrm{R})$ of 0.8231 which means the relationship between learning discipline, learning interest and learning environment at home with mathematics learning outcomes has a moderate relationship. In this study also obtained a coefficient of determination $\left(\mathrm{R}^{2}\right)$ of 0.677559 . The variation in mathematics learning outcomes $(\mathrm{Y})$ can be explained by the discipline of learning $\left(\mathrm{X}_{1}\right)$, interest in learning $\left(\mathrm{X}_{2}\right)$, and the learning environment at home $\left(\mathrm{X}_{3}\right)$ through linear lines $\hat{Y}=$ $-193,541+1,465 X_{1}+1,047 X_{2}+0,35 X_{3}$.

\section{CONCLUSION}

Based on the results of research and discussion, the conclusions can be drawn, namely:

a. There is a positive and significant relationship between learning discipline and mathematics learning outcomes of Grade VIII students of SMP Negeri 15 Yogyakarta in the academic year $2015 / 2016$.

b. There is a positive and significant relationship between interest in learning with mathematics learning outcomes for students of class VIII of SMP Negeri 15 Yogyakarta in the academic year 2015/2016.

c. There is a positive and significant relationship between the learning environment at home with the mathematics learning outcomes of Grade VIII students of SMP Negeri 15 Yogyakarta in the academic year 2015/2016.

d. There is a positive and significant relationship between learning discipline and learning interest with the learning outcomes of Grade VIII students of SMP Negeri 15 Yogyakarta in the 2015/2016 academic year.

e. There is a positive and significant relationship between learning discipline and the learning environment at home with the mathematics learning outcomes of Grade VIII students of SMP Negeri 15 Yogyakarta in the 2015/2016 academic year.

f. There is a positive and significant relationship between interest in learning and the learning environment at home mathematics with the learning outcomes of eighth-grade students of SMP Negeri 15 Yogyakarta in the academic year 2015/2016.

g. There is a positive and significant relationship between learning discipline, interest in learning and the learning environment at home with mathematics learning outcomes for students of class VIII at SMP Negeri 15 Yogyakarta in the academic year 2015/2016.

\section{REFERENCES}

Arikunto, Suharsimi. 2012. Dasar - Dasar Evaluasi Pendidikan. Jakarta : Bumi Aksara.

Moenir, A S. 2006. Manajemen Pelayanan Umum di Indonesia. Jakarta : Bumi Aksara.

Slameto. 2010. Belajar dan Faktor - Faktor yang Mempengaruhi. Jakarta : Rineka Cipta.

Syah, Muhibbin. 2004. Psikologi Pendidikan Dengan Pendekatan Baru. Bandung : Remaja Rosdakarya.

Winkel, W.S. 1996. Psikologi Pengajaran. Jakarta : Grasindo. 